UDC 821.161.1

Marina Koreneva, Gerta Monakhova, Svetlana Stepina

The Institute of Russian Literature (Pushkin House)

of the Russian Academy of Sciences

\title{
TRAVEL OF YOUNG RUSSIAN 'LIBERAL' TO HOLLAND IN 1811 (BASED ON THE UNPUBLISHED JOURNAL BY SERGEI IVANOVICH TURGENEV)*
}

For citation: Koreneva M., Monakhova G., Stepina S. Travel of young Russian 'liberal' to Holland in 1811 (based on the unpublished journal by Sergei Ivanovich Turgenev. Scandinavian Philology, 2019, vol. 17, issue 2, pp. 350-364.

https://doi.org/10.21638/11701/spbu21.2019.211

The article is the first to introduce into scholarly discourse the unpublished journal of S. I. Turgenev (1792-1827) from the Turgenev brothers' archive at the Institute of Russian Literature of the Russian Academy of Sciences, which is a unique collection of manuscripts related to the history of Russian-European cultural relations in the first half of the $19^{\text {th }}$ century. Turgenev's journal dates back to 1811, when he, a young 'liberal,' a future diplomat, studied at the University of Göttingen and during his vacation travelled to 'French' Holland to see with his own eyes Napoleon, who arrived in Amsterdam almost at the same time as the Russian student. The deciphered text contains a lot of valuable observations about the everyday life of the Dutch people of that time, about the organization of socially important public institutions (hospitals, nursing homes, orphanages, etc.), about the practical side of organizing travel for foreigners, and also includes reflections on the nature of political obedience, on optimal forms of government in general and for Holland in particular. Of special interest here is the description of the reception given by the people of Amsterdam to the French Emperor, whom the Russian traveller regards as the greatest conqueror and at the same time the greatest monarch. The journal allows us to trace how his first-hand observations become the basis for creating a personal image of Holland, which is further enriched and modified on the basis of information obtained from books (O. Goldsmith, A. Smith, etc.). The journal shows how all sorts of diverse impressions interact to form a signifi-

* Исследование выполнено при финансовой поддержке РФФИ в рамках научного проекта № 18-012-00-478 (The reported study was funded by RFBR, project No. 18-012-00-478). 
cant intellectual arsenal of a Russian liberal, who is a convinced European. We can see how important this intellectual arsenal becomes for his further individual and professional development, as evidenced by the later journals of S. I. Turgenev, relating to 1815, when he served in Paris, as a member of the Russian expeditionary force, and worked on a draft constitution for Russia.

Keywords: S. I. Turgenev, pragmatics of travelling, Holland during the Napoleonic era, Napoleon in Amsterdam in 1811, Russian-Dutch cultural ties at the beginning of the $19^{\text {th }}$ century, Russian liberalism, political values in the era of global changes.

One of the important sources to have shaped the history of cultural links between Holland and Russia are personal journals by Russian travellers. Of particular interest are the journals of those travellers who didn't find themselves in Holland for reasons of work or as a consequence of some historic events but went there out of pure interest and curiosity as anonymous ordinary people and recorded their impressions of that country, about which Russians in the early 19th century only had a very vague and general idea. One of those 'ordinary people' was Sergei Ivanovich Turgenev (1792-1827), a future diplomat and a younger brother of Alexander Ivanovich Turgenev (1784-1845), a notable statesman and a well-known author of literary and political chronicles, and Nikolai Ivanovich Turgenev (1789-1871), a famous economist, who was subsequently sentenced in absentia to death as an 'ideologue' of an unsuccessful uprising in December 1825. In fact, none of the brothers were 'ordinary' or 'common people' in the sense we use these words today. Each of them, to a greater or lesser extent, made a mark on Russian history. However, in the early 1810s they had just begun to gain some independence and were some unknown typical representatives of the enlightened nobility, who were brought up in a liberal spirit, which was combined with their love for their homeland, instilled in them from childhood.

In 1810 Sergei Ivanovich Turgenev was enrolled at the University of Göttingen, where his older brothers had also studied (Alexander in 1802-1804, Nikolai - in 1808-1811), with whom he was bound by the closest ties of friendship: abroad for the first in his life, S. I. Turgenev regularly writes to them, tells them about his student life, and asks for their advise on various issues. In the autumn of 1811, during his university vacation, S. I. Turgenev decided to go on a trip along the Rhine but his brother Nikolai talked him out of this plan. 'You want to go to the Rhine. It's a German habit, brother, eine Rheinreise machen 
(to make a trip along the Rhine). Now the Rhine is not what it used to be, and you can have a lot of trouble because of the Fr $<$ ench $>$ border fortresses $\langle\ldots\rangle$. If you want to make a trip, go to Hamburg; from there to Amsterdam, etc., and come back via Münster and Paderborn. That way you'll see a part of the Rhine and you can have an idea of the whole thing. It will cost more time and money; but at least you will be able to see something; and just taking a trip along the Rhine isn't worth coming all the way from Göttingen,' wrote N. I. Turgenev on September 7, 1811, from Paris [Turgenev N. I., 1936, p. 96-97]. In fact, a year before N. I. Turgenev himself visited Holland: in May 1810, as a student at the University of Göttingen, he took advantage of his vacation to visit the Kingdom of Holland, which had already lost its status of a kingdom in July 1810 because Napoleon I, dissatisfied with the policies of his brother Louis (Louis Bonaparte, 1778-1846), whom he had appointed king in June 1806, had joined Holland to France as a department. N. I. Turgenev spent almost five weeks in Holland and looked back on his journey with pleasure, although the country itself made an ambivalent impression on him. '...I saw Holland, I was surprised at the intelligence, art, and omnipotence of people who triumphed over the nature; they built towns on the waters, created fields out of the swamps, enriched the former, cultivated the latter, and put this wonderful land to the level of perfection that no other land in Europe had yet! Wherever you go, you can see the hard work and prosperity that reign in Holland, he wrote to his brother Alexander Ivanovich Turgenev on May 23, 1810 [Turgenev N.I., 1911, p. 395]. This overall positive picture is complemented by reflections on the changes that took place in Holland, '... only traces of the old greatness remain,' he goes on to write, 'just memories of the past and - maybe - hope! The change in the national character also had a great part to do with this change; who would have thought before that most of the native Dutchmen, who were rightly proud of their freedom, were going to turn into the most empty people, proud of their gold uniforms, ribbons, etc.? However, that's what people are like!' [Turgenev N.I., 1911, p. 395]. The same duality is found in the attitude of Nikolai Ivanovich Turgenev towards the Kingdom of Westphalia, to which Göttingen belonged. On the one hand, the years he spent there gave him a subjective sense of 'freedom, independence and peace - in the very real sense of these words,' as he wrote in his journal at the end of his studies in June 1811 
[Turgenev N. I., 1913, p. 8]. On the other hand, he couldn't escape the feeling that there was a lack of freedom in that newly formed state, led by Napoleon's younger brother, King Jerome (Jérôme Bonaparte, 1784-1860). In his journal N. I. Turgenev always refers to King Jerome as 'Yeryoma,' which demonstrates his disdain for that ruler, who on acceding to the throne, abolished serfdom, introduced the Constitution and the Napoleonic Code, which equalized the rights of all citizens, etc., - the reforms that evidently escaped the attention of the young Russian student. The record made by N. I. Turgenev on January 4, 1810 after his trip to the capital of the Kingdom of Westphalia is quite indicative in this sense, 'I didn't like Kassel very much; and how can you possibly like a place where the Napoleons reign?' [Turgenev N. I., 1911, p. 234]. This aversion to 'Napoleons' did not prevent N. I. Turgenev from strongly recommending his brother Sergei Ivanovich Turgenev to go to Holland. What is more, as an additional argument in favour of such a trip, he points to the possibility of seeing the French Emperor himself, who was rumoured to be visiting Amsterdam at that time [Turgenev N. I., 1936, p. 101] ${ }^{1}$. The last argument turns out to be important for S. I. Turgenev: after leaving for his trip on September 11, 1811, he stops in Hamburg, which was annexed to the French Empire in 1806, but hurries to Amsterdam so as not to miss Napoleon's arrival. Although he had another, perhaps even more important goal for him - to get to see the performances of the French troupe, that came to Amsterdam from Paris, and enjoy the acting of Napoleon's favourite, the famous actor F.-J. Talma (François-Joseph Talma, 1763-1826)2 These two 'shows' were almost equally attractive for S. I. Turgenev but the interest in the latter clearly prevailed. Anyway, when already in Amsterdam, after his unsuccessful attempts to get good tickets to the performance with the participation of the idol of the French theatre public, he decides on an unusual step, 'I will go to Talma and, telling him that I came to Amsterdam for him (I was not sure if the Emperor would be here), I will ask him to provide me with the means to see and hear him on stage. It will be a shame if it doesn't work out. Then it will be necessary to go to the theatre and be squeezed in the crowd.

${ }^{1}$ Napoleon arrived in Amsterdam on October 9, 1811; this was his first official visit to the "third city of the empire". For more details see: [Sor, 1841].

${ }^{2}$ For more details about Talma's performances in Amsterdam in the autumn of 1811 see: [Chevalley, 1988]. 
However, out of love for art it can be endured. At least I will see Talma' [Turgenev N. I., 1811-1812, 1. 74].

For S. I. Turgenev it was his first trip on his own outside the German lands. His journal contains a lot of everyday details, which allow one to get an idea of how such a trip abroad was organized and what difficulties it was associated with. One of the main organizational challenges for a travelling foreigner was obtaining entry and exit permits. Upon his arrival in Hamburg on September 14, S. I. Turgenev went to the police to find out whether he could go to Holland with a passport of the 'friendly' Kingdom of Westphalia or whether he should obtain a new French one [Turgenev S. I., 1811-1812, 1. 50]. That trip to the police served as an occasion for a vivid 'sketch from life': in his journal S.I. Turgenev describes ironically how the doorkeeper tried to escort him out of the waiting room and ordered him to 'stand with the people' because 'before the law, all are equal' [Turgenev S. I., 1811$1812,1.50$ ], but the clerks brought him back, asked him to sit down, and wait until his matter was resolved. 'He who is dressed in cleaner clothes should have a cleaner bench', writes S. I. Turgenev concluding the description of this scene [Turgenev S. I., 1811-1812, 1. 50]. After arriving in Amsterdam, Turgenev again goes to the police, this time to obtain a residence permit in Holland. A foreigner was granted such a permit for a period of eight days and only in case when there were two guarantors available then a temporary identification card was issued to allow for longer stays [Turgenev S. I., 1811-1812, 1. 68 ob.]. 'It's a new rigour here,' points out S. I. Turgenev [Turgenev S. I., 1811-1812, 1. 69]. On October 3, thanks to the guarantee provided by the Russian Consul General Ivan Ivanovich Smirnov, S. I. Turgenev received a one-month temporary residence card [Turgenev S.I., 1811-1812, 1. 83]. However, he left Holland somewhat earlier. On October 16 he already left Amsterdam, and reached Kassel on October 25. On the eve of his departure, on October 15, he had to go back to the police to get the required stamp in his passport but he was unable to get it. According to the police officer, to get an exit visa, one had to obtain the approval of the Minister in Paris [Turgenev S. I., 1811-1812, 1. 104]. 'When I asked what I was supposed to do, they told me I could travel with that passport anyway. Why on earth say with a desperate face that it was impossible and so on and scare a foreigner with the name of the Emperor and so forth? Yet God is with them! As long as I wouldn't 
get any trouble when travelling,' writes S. I. Turgenev [Turgenev S. I., 1811-1812, 1. 104].

In addition to visa matters, the young traveller in Holland had a lot of other things to worry about: to settle in a hotel, find a suitable lohnlakai (a local footman), settle the money issues, etc. The hotels were all overcrowded due to the expected arrival of the emperor and some of the people accompanying the emperor even were to stay in private houses. At that time when travelling abroad it was customary to hire a lohnlakai who was supposed to act as a guide and assist in solving everyday problems. S. I. Turgenev didn't have much luck with the footman he hired: Louis, a Swiss, was often drunk, seldom on time and always tried to cheat, which meant that the inexperienced foreigner was doomed to incur additional costs, and that was quite a painful problem for S. I. Turgenev, who was already short of money. He hadn't considered the matter of the cash beforehand and he already spent everything he had in Hamburg. So much so that he couldn't even pay for the boat that brought him from the ship to shore in Amsterdam, and a fellow traveller paid the fare for him [Turgenev S. I., 1811-1812, 1. $65 \mathrm{ob}$.]. As a result, S. I. Turgenev had to turn for help to Johann Goll van Frankenstein (1756-1821), a banker from Amsterdam, who, taking into account the provided recommendation letters and a guarantee from the Russian Consul I. I. Smirnov, gave him the necessary amount of money for a bill of exchange, which S. I. Turgenev promised to pay off after returning to Göttingen, expecting to receive money from his mother.

All these small and big problems, however, were fully compensated for with new impressions, for the sake of which S. I. Turgenev embarked on his journey. There was also a literary reference point for this trip - A Sentimental Journey through France and Italy (1768) by Lawrence Stern (1713-1768), which for S. I. Turgenev, like for many of his contemporaries, served as some sort of a 'guiding reference' in his travel. L. Stern identifies eleven types of travellers: idle, inquisitive, lying, proud, vain, splenetic, the delinquent and felonious traveller, the unfortunate and innocent traveller, the simple traveller, the sentimental traveller [Stern, 1768, p. 27-28]. S. I. Turgenev considered himself to be an 'inquisitive' traveller, for whom a journey is a kind of encyclopaedia, and at the same time a 'sensitive' traveller, understanding by the latter those who travel exclusively for the sake of getting 'their own pleasure' 
[Turgenev S. I., 1811-1812, 1. 36, 58-58 ob.]. This typical of the epoch focus on combining the useful and the pleasant determined S. I. Turgenev's schedules while he visited Dutch cities. Part of the day he devoted to visiting various city institutions, and in the evenings he went to the theatres.

Among the public institutions, which S.I. Turgenev diligently visited in Amsterdam, were an institution for the blind, an orphanage for foundlings and orphans, a hospice, a workhouse, a variety of medical institutions, including a hospital for people suffering from venereal diseases, which he visited together with the consul and a specially invited doctor, who gave explanations. Everywhere Turgenev paid attention to the conditions of living, nutrition, and general organization, noticing individual details, looking at various human types, and collecting information about how all these socially important institutions were run. From the point of view of the young Russian traveller, such observations were important to enrich his practical skills and knowledge, which could be of use later upon his return to his homeland. Such visits were not unusual at the time: they did not usually require any special permission or prior arrangement, and anyone interested was freely allowed to visit. In any case, all the guidebooks by Henry August Ottokar Reichard (1751-1828), which were particularly popular among travellers, always pointed out the public institutions of various kinds worth visiting. S. I. Turgenev as well had a Reichard's guide at his disposal and, although in moments of anger he scolded the famous author, calling him 'a swine' for the discrepancies between the descriptions in the guidebook and the reality he saw [Turgenev S. I., 1811-1812, 1. 41 ob.], still he followed his advice in general but also showed some independence: the list of institutions he visited included those that were not mentioned by Reichard. It is noteworthy that S. I. Turgenev's older brothers, Nikolai and Alexander, also behaved in the same way during their travels abroad: no matter where they found themselves, in Germany, Austria, France, Italy or England, they invariably visited the most important social institutions, comparing their observations with the reality in Russia.

With as much interest S. I. Turgenev also visited local churches. During his stay in Amsterdam, he visited several Catholic and Protestant temples, an Armenian church, as well as two synagogues, where he was particularly impressed by the unusual environment: 'So much shouting! If they addressed their pleas not to God, but to a man, I think their re- 
quests would always be fulfilled. To get rid of their screaming, I imagine I would do anything for them. Such a cacophony of numerous voices, nothing for the eyes, nothing for the heart, nothing for the mind' [Turgenev S. I., 1811-1812, 1. 91]. However, most often he visited the Greek Orthodox church (the temple of St. Catherine), which he discovered almost immediately upon his arrival: '...I hurried to the Greek church. $<\ldots>$ How nice it was to be in a church where you belong. I gladly put the guilder on a dish. The service was in $\mathrm{Gr}<\mathrm{eek}>$. The prayer for Emperor Napoleon was in Latin, and the Litany before the Lord's Prayer and the prayer itself were in Russian. $\langle\ldots\rangle$ The church is small but seems to be sufficient for parishioners; and it is clean there as everywhere here. $\langle\ldots\rangle$ There were no other Russians there except me. The Greeks guessed that I was Russian and came up to me, speaking French. They invited me to come to the mass on Sunday, wrote down S. I. Turgenev on September 29 [Turgenev S. I., 1811-1812, 1. $71 \mathrm{ob}$.]. This joy of being able to visit a church 'where you belong' is quite understandable, given the fact that in Göttingen, where S. I. Turgenev studied, there was no Orthodox church.

Most of the time that S. I. Turgenev had for his travel to Holland he spent in Amsterdam, hoping to see the French emperor. And only once he made a short trip to Sardam (Zaandam) to visit the famous house of Peter I, where the Russian Emperor lived for eight days in 1697 under the name of Peter Mikhailov, when he came there to study shipbuilding. This private 'museum,' run by a local enterprising innkeeper who bought both the house and the plot of land, was a sort of pilgrimage site for many Russians who came to Holland before and after S. I. Turgenev. The modest home of the 'greatest of the monarchs,' as the young S.I. Turgenev calls him in his journal, made an exciting impression on him: 'I was fascinated. I touched every object in the hut. I stared at his alcove bed for a long time, took off his portrait and kissed it, and was unable to stop looking at it. My fellow visitors may have been surprised at first, but having learned that I am Russian they certainly understood the reason for my chaotic movements. $<\ldots>$ on my orders, Louis (his footman. $-E d$.), broke off a piece of wood with a nail from the door ... for me to keep it. Yesterday a lady, who had learned about that incident from someone, told me that if all the Russians had been such admirers of Peter I, the hut would not have lasted long. But I wanted to get just a little piece; who on earth could 
think that the footman would chip off such a huge chunk. We wrote down our names in the guest book. While I was turning over the pages in the book, I came across a remark, which was probably written by a Frenchman. He claims 'qu'il révère ton individualité, o Pierre, mais qu'il craint pour les suites de l'agrandissement de la Russie' [that he admires your individuality, o Peter, but that he fears for the consequences of the expansion of Russia]. He believes that greatness, founded by Peter, is harmful to the whole world or at least to enlightened Europe' [Turgenev S. I., 1811-1812, 1. 81-81 ob.]. Turgenev himself felt part of this renewed Russia, 'not a Scythian, but a Russian with noble thoughts' [Turgenev S. I., 1811-1812, 1. 87 ob.]; and in everyday life, while travelling, he did not encounter any unpleasant attitude towards himself, which would conceal the fearful attitude towards Russia expressed by the unknown Frenchman who signed his entry as A Friend of Harmony. In fact, S. I. Turgenev's journal shows only one episode when he did feel hostility towards himself from others. However, that episode was due to the fact that he was mistaken for a Frenchman (since the main language of communication for him during his trip was French and less often German). 'What a god-damn thing! Just had an encounter with a drunken barber who was brought up in Paris and who thought I came from France,' writes S. I. Turgenev on the second day of his stay in Amsterdam, on September 28. - 'Do I really look like a Frenchman to them? More: Yesterday the one who brought me here told me that he, his friend, and all the servicemen of the ship did not treat me very well at first because they thought I was French. But when he told them, they became much more polite and kind. Probably, I owe this misunderstanding to the fact that I do not speak Dutch but French [Turgenev S. I., 1811-1812, 1. 67 ob.-68].

The 'French line' becomes a recurrent theme in S. I. Turgenev's travel journal; when looking at the everyday life of the Dutch people, he tries to understand their attitude to the new regime, to reflect on the pluses and minuses of the changes that occurred due to the incorporation of Holland into the French state. Having come there with the ready-made knowledge that the once rich country was in political slavery, he initially looked at everything through the prism of the latest historical events. Even the 'classic' Dutch landscapes that he saw while still aboard the ship, although he admired them tremendously, did suggest to him an idea that these idyllic landscapes did not correspond to the actual re- 
ality, which was the absence of freedom in Holland: 'Quel pays! I exclaimed, as I stood on the deck and saw beautiful villages and meadows. And indeed, who wouldn't think that the people who live here are the happiest in the world? But no! These are just remnants of happiness. Now the hand of the strong is a burden to the wise' [Turgenev S.I., 1811-1812, 1. 63]. However, after spending a few days in Amsterdam, S.I. Turgenev discovers with some surprise that on the whole the locals had adapted to the new situation and did not particularly complain. Turgenev was unaware of the fact that several months before his arrival, in April 1811, large-scale riots took place in Amsterdam that were caused by the new conscription law [Jor, 2012, p. 272], nor did he know about the existence of active anti-Napoleonic 'propaganda.' He formed his opinion about the attitude towards the French government on the basis of his conversations with casual acquaintances: 'Here, they say, they are more accustomed to the new government, and even prosperous people do seek to occupy government positions, while in Hamburg they do not like all the officials, especially the French [Turgenev S.I., 1811-1812, 1. 85 ob.]. Such conversations make the young Russian student reflect on the reasons for the apparent civil obedience. In fact, these reflections are a characteristic feature of that time, marked by the spirit of global change, which began with the revolutions in France and continued with a series of European wars, resulting in redrawing of the state borders, as well as changes in the forms of government. All of these factors contributed to subjective readiness for sweeping changes. Such subjective readiness can be seen in S.I. Turgenev's journal: his reasoning about the obedience of the Dutch in the Napoleonic era somehow implies that there was an alternative in the form of protest. The absence of protest S. I. Turgenev explains for himself by the prosperity of the country and the personal wealth of individual citizens: 'It's true that wealth makes people more indifferent to freedom, and that the poor are always brave. But then doesn't wealth bind people to their homeland more, and isn't it easier for the poor to change their position, their rulers? Doesn't the hope of improving their condition deceive the poor more than people of sufficient means? - The humiliation of the Dutch should be sought further up, in remote times, and finally in their character. When were they great? Back then, when great men ruled them. But when the princes of Orange ceased to be like that, the decline of the army and even the navy had already foreshadowed 
the decline of the country' [Turgenev S.I., 1811-1812, 1. 101 ob.]. The idea of a direct correlation between the degree of political loyalty and the welfare of society was not new: as regards Holland, it had already been expressed in a poetic form by Oliver Goldsmith (1728-1774) in his philosophical poem The Traveller, or Prospect of Society (1764), in which the author gave a detailed disparaging portrayal of the country, which, in his view, was driven by greed:

Hence all the good from opulence that springs,

With all those ills superfluous treasure brings,

Are here displayed. Their much-loved wealth imparts

Convenience, plenty, elegance, and arts;

But view them closer, craft and fraud appear,

Even liberty itself is bartered here.

At gold's superior charms all freedom flies,

The needy sell it, and the rich man buys.

A land of tyrants, and a den of slaves,

Here wretches seek dishonourable graves,

And, calmly bent, to servitude conform,

Dull as their lakes that slumber in the storm [Goldsmith, 1936, p. 15].

S. I. Turgenev read this book after returning to Göttingen. He did not like the verses about Holland and he considered the harsh judgments of Goldsmith to be unfair [Turgenev S. I., 1811-1812, 1. 110]. While disagreeing with the harsh verdict to Holland passed by the poet, S.I. Turgenev could not clearly assess for himself the political reality he had come into contact with during his brief stay in the country. For him, Napoleon is not a tyrant, yet a conqueror, hence the young Russian nobleman, an admirer of French culture, is constantly changing his attitude towards Napoleon. While waiting for the arrival of the French Emperor, S. I. Turgenev writes, 'So I'll see Napoleon. More than anything else, what should I look at when I see him? They say at his eyes... And truly. I'll see with what kind of eyes he's looking at the people who are plunged into misery because of him. Entire lands! <...> Indeed, here things were good even without the French. One man! But he is mortal - a sad consolation! [Turgenev S. I., 1811-1812, 1. 95]. However, a little later on, he speaks of Napoleon in a different way and calls him a 'great monarch', who 'came to Holland for the benefit of his new children and works for them from early morning till night' [Turgenev S. I., 1811-1812, 1. 131], and concludes that the annexation of Holland by France, at least from an economic point of view, 
may even be beneficial [Turgenev S. I., 1811-1812, 1. 87 ob.]. Such duality is a result of combining two perspectives, which could be conventionally defined as long and short-term perspectives. The first one is abstract and speculative and it is based on certain knowledge as well as a set of ideas typical of the era of global changes; the second one is subjective, based on direct observations of an 'outsider,' who, although he feels himself a European, yet does not identify himself with the people of the country he is visiting. Within the subjective, short-term perspective, Napoleon is still a 'great hero', born of the French spirit and who for S. I. Turgenev is on a par with Voltaire and Talma [Turgenev S. I., 1811-1812, 1. 130], a genius who deserves poems, songs, operas, and plays to be dedicated to him. In fact, one of them S.I. Turgenev personally attended. It was a one-act musical play Le Chantier de Saardam, ou L'impromtu hollandais by the French playwright René de Chazet (1774-1844), composed in 1811 on the occasion of the Dutch voyage of Napoleon and his wife. The audience liked one of the musical numbers (a march) so much that many spectators began to sing, repeating the refrain 'Vive Louise, vive Napoléon' [Chazet, 1811 , p. 51-55]. S. I. Turgenev was among those singing. Not only did he note this fact in his journal but he also wrote down one of the verses he remembered [Turgenev S. I., 1811-1812, 1. 148]. His own enthusiasm, with which he praised the 'other people's' conqueror, did not prevent S. I. Turgenev from criticizing the Dutch for too great manifestation of loyalty, which he observed during those days. 'Yesterday, after the theatre, I spoke downstairs with a Dutchman who saw the Emperor in Utrecht. He was ... well received there. He saw how His $\operatorname{Imp}<$ erial $>$ Maj<esty $>$ was eating. I wished him to see how he was pooping, and I whispered this to the landlady' [Turgenev S. I., 1811-1812, 1. 95]. This rather frivolous remark could have brought serious trouble to the Russian student, given the number of secret police agents who were 'working' in theatres, taverns, churches, eavesdropping on conversations and identifying politically unreliable people [Jor, 2012, p. 274]. However, there were no consequences, and S.I.Turgenev, having spent a little more than two weeks in Amsterdam, on October 16 starts on his journey back, without even taking the opportunity to go the ball, which was given on October 22 in honour of Napoleon and his wife in the building of the city philanthropic society Felix Meritis. He left without much 'sadness' [Turgenev S. I., 1811-1812, 1. 105] but full of the most pleasant impressions, which, however, quite soon were relegated to the background, giving way to general reflections 
on the forms of government most suitable for Holland. Reflections of this kind were inspired by the work of the Scottish economist Adam Smith (1723-1790) An inquiry into the nature and causes of the wealth of nations (1776), which was very popular in Russia at the time and which S.I.Turgenev read upon his return to Göttingen. He wrote down extensive extracts from it, mainly from the 'Dutch' part of the book, where it is argued that only the republican system can retain capital and preserve the welfare of this rich country [Smith, 1811, p. 316].

Thus, the Dutch trip became an opportunity for intellectual enrichment of the young Russian 'liberal,' who in a few years, in 1815, was to serve in Paris, under Count M.S. Vorontsov (1782-1856), as a member of the Russian expeditionary force, and, among other things, to devote many hours of his leisure time to writing the draft constitution for Russia.

\section{REFERENCES}

Jor J. The protest movement and anti-Napoleonic propaganda in Holland in 1806-1813. Transl. from English by E. A. Prusskaia. Frantsuzskii ezhegodnik 2012: 200 let Otechestvennoi voiny 1812 goda. Moscow, 2012. P. 265-294. (In Russian)

Turgenev N. I. Journals and letters of 1806-1811. Arhiv brat'ev Turgenevyh. Iss. 1, vol. 1. St. Petersburg, 1911. 512 p. (In Russian)

Turgenev N. I. Journals and letters of 1811-1816. Arhiv brat'ev Turgenevyh. Iss. 3, vol. 2. St. Petersburg, 1913. 501 p. (In Russian)

Turgenev N. I. Letters to brother S. I. Turgenev 1811-1824 (Decembrist N. I. Turgenev). Moscow; Leningrad, 1936. 587 p. (In Russian)

Turgenev S. I. Travel notes from Göttingen to St. Petersburg 1811-1812. Rukopisnyi otdel Instituta russkoi literatury (Pushkinskii Dom) RAN f. 309, ed. khr. No. 19. 286 p. (In Russian)

Chazet R. de. Le Chantier de Saardam, ou l'impromptu hollandaise. Amsterdam, $1811.55 \mathrm{p}$.

Chevalley S. Politique et Théâtre. Une visite impérial en Hollande en 1811. Revue du Souvenir Napoléonien. Vol. 359. Paris, 1988. P. 13-18.

Goldsmith O. The Traveller and The Deserted Village. Cambridge, 1936. 87 p.

Smith A. An Inquiry into the Nature and Causes of the Wealth of Nations. Vol. 2. Hartford, 1811. 424 p.

Sor Ch. de. Napoléon en Belgique et en Holland 1811. Paris, 1841. 404 p.

Stern L. A Sentimental Journey through France and Italy. Vol. 1. London, 1768. $203 \mathrm{p}$. 
Марина Коренева, Герта Монахова, Светлана Степина

Институт русской литературы (Пушкинский Дом) РАН

\section{ПУТЕШЕСТВИЕ В ГОЛЛАНДИЮ МОЛОДОГО РУССКОГО «ЛИБЕРАЛА» В 1811 г. (НА МАТЕРИАЛЕ НЕОПУБЛИКОВАННОГО ДНЕВНИКА СЕРГЕЙ ИВАНОВИЧА ТУРГЕНЕВА)}

Для цитирования: Koreneva M., Monakhova G., Stepina S. Travel of young Russian 'liberal' to Holland in 1811 (based on the unpublished journal by Sergei Ivanovich Turgenev // Скандинавская филология. 2019. Т. 17. Вып. 2. С. 350-364. https://doi.org/10.21638/11701/spbu21.2019.211

В статье впервые вводится в научный оборот неопубликованный дневник С.И. Тургенева (1792-1827) из архива братьев Тургеневых, хранящегося в Институте русской литературы РАН и представляющего собой уникальное собрание рукописных документов по истории русско-европейских культурных связей первой половины XIX в. Дневник С.И. Тургенева относится к 1811 г., когда он, молодой «либерал», будущий дипломат, учился в Гёттингенском университете и на каникулах совершил путешествие во «французскую» Голландию, чтобы увидеть собственными глазами Наполеона, прибывшего в Амстердам почти одновременно с русским студентом. Расшифрованный текст содержит в себе множество ценных наблюдений о повседневной жизни голландцев этого времени, об устройстве социально значимых государственных заведений (больницы, дома престарелых, приюты и пр.), о практической стороне организации путешествия для иностранца, а также включает в себя размышления о природе политической покорности, об оптимальных формах государственного устройства вообще и для Голландии в частности. Особое место здесь занимает описание приема, который был оказан жителями Амстердама французскому императору, который видится русскому путешественнику величайшим завоевателем и одновременно величайшим монархом. Дневник позволяет проследить, как из непосредственных наблюдений рождается субъективный образ Голландии, на который накладываются сведения, полученные из книг (О. Голдсмита, А. Смита и др.), а также увидеть, как из всех этих разнообразных впечатлений формируется интеллектуальный багаж русского европейца-либерала, значимый для его дальнейшего индивидуального и профессионального развития, о чем свидетельствуют более поздние дневники С. И. Тургенева, относящиеся к 1815 г., когда он служил в Париже в составе Русского экспедиционного корпуса и составлял проект конституции для России.

Ключевые слова: С. И. Тургенев, прагматика путешествия, Голландия в эпоху Наполеона, Наполеон в Амстердаме 1811 г., русско-голландские культурные связи начала XIX в., русский либерализм, политические ценности в эпоху глобальных сдвигов.

\section{Marina Koreneva}

$\mathrm{PhD}$ in philology, leading researcher,

The Institute of Russian Literature (Pushkin House)

of the Russian Academy of Sciences,

4, Makarova nab., 199034, St. Petersburg, Russia

E-mail: marinakoreneva7@gmail.com 


\section{Коренева Марина Юрьевна}

кандидат филологических наук, ведущий научный сотрудник,

Институт русской литературы (Пушкинский Дом) РАН,

Россия, 199034, Санкт-Петербург, наб. Макарова, 4

E-mail: marinakoreneva7@gmail.com

\section{Gerta Monakhova}

junior researcher,

The Institute of Russian Literature (Pushkin House)

of the Russian Academy of Sciences,

4, Makarova nab., 199034, St. Petersburg, Russia

E-mail: gertaff@gmail.com

\section{Монахова Герта Рашидовна}

младший научный сотрудник,

Институт русской литературы (Пушкинский Дом) РАН, Россия, 199034, Санкт-Петербург, наб. Макарова, 4

E-mail: gertaff@gmail.com

\section{Svetlana Stepina}

junior researcher,

The Institute of Russian Literature (Pushkin House)

of the Russian Academy of Sciences,

4, Makarova nab., 199034, St. Petersburg, Russia

E-mail: sa.styopina@gmail.com

\section{Степина Светлана Александровна}

младший научный сотрудник,

Институт русской литературы (Пушкинский Дом) РАН,

Россия, 199034, Санкт-Петербург, наб. Макарова, 4

E-mail: sa.styopina@gmail.com 